\title{
Duality by Design: The Global Race to Build Africa's Infrastructure
}

\section{Document Version}

Accepted author manuscript

Link to publication record in Manchester Research Explorer

\section{Citation for published version (APA):}

Gil, N., \& Stafford, A. (Accepted/In press). Duality by Design: The Global Race to Build Africa's Infrastructure. Cambridge University Press.

\section{Citing this paper}

Please note that where the full-text provided on Manchester Research Explorer is the Author Accepted Manuscript or Proof version this may differ from the final Published version. If citing, it is advised that you check and use the publisher's definitive version.

\section{General rights}

Copyright and moral rights for the publications made accessible in the Research Explorer are retained by the authors and/or other copyright owners and it is a condition of accessing publications that users recognise and abide by the legal requirements associated with these rights.

\section{Takedown policy}

If you believe that this document breaches copyright please refer to the University of Manchester's Takedown Procedures [http://man.ac.uk/04Y6Bo] or contact uml.scholarlycommunications@manchester.ac.uk providing relevant details, so we can investigate your claim.

\section{OPEN ACCESS}




\section{Duality by Design}

The Global Race to Build

Africa's Infrastructure

Edited by Nuno Gil, Anne Stafford and Innocent Musonda

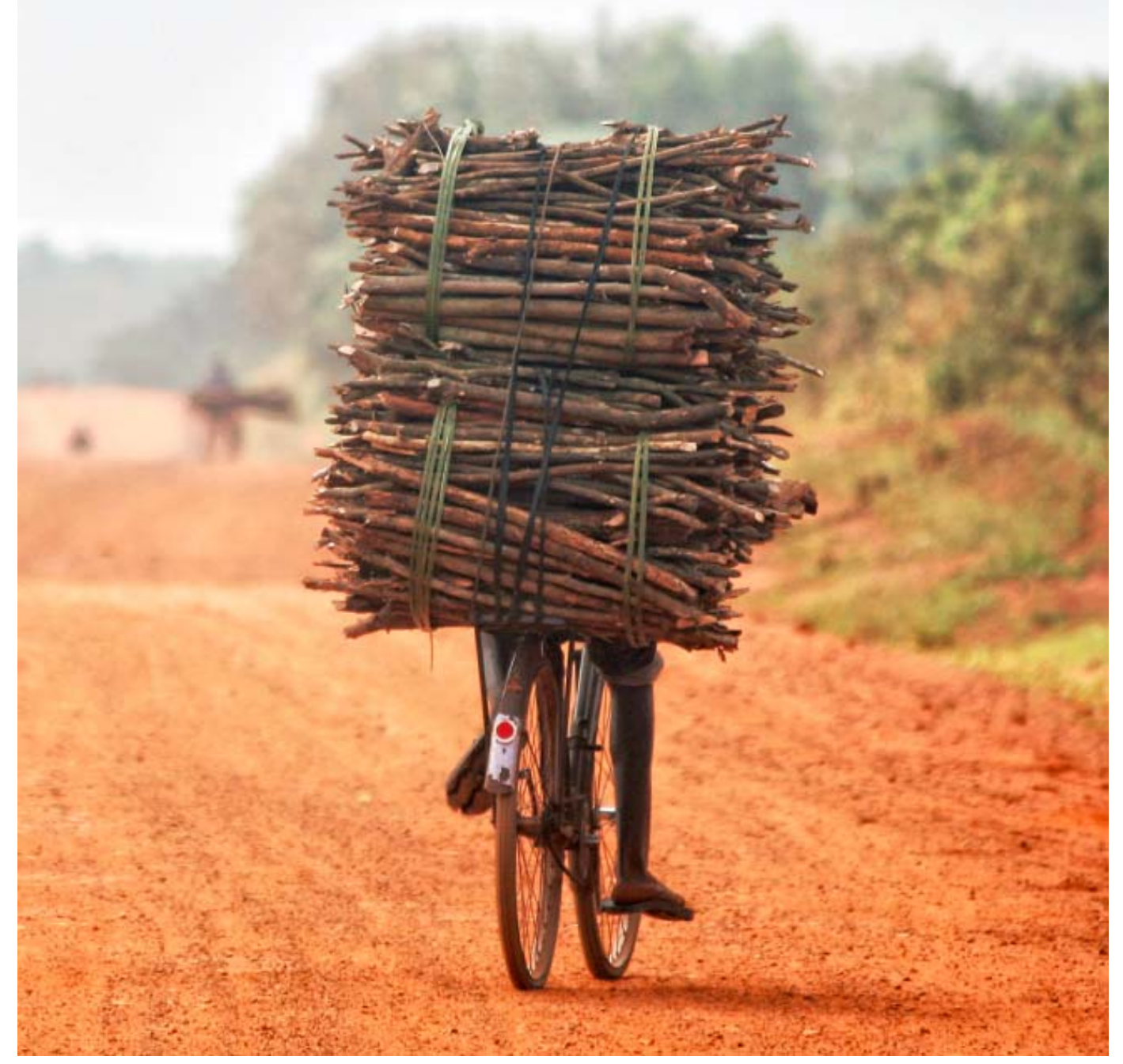

(forthcoming Cambridge University Press) 


\section{FOREWORD}

Most academics, if they are honest, will admit to living with a constant worry about the usefulness of the theoretical exercises that they engage in. Worse, there is the creeping guilt that what we enjoy doing may be contributing too little to the solution of really important problems in the world. The current volume goes a long way to reassure researchers and practitioners that sound theory and careful research have much of value to say to those engaged in trying to solve important real world problems.

The creation of infrastructure in Africa is arguably one of the top global concerns for this decade. "Failure to act, and make Africa a better place to live and work, will saddle future generations with a major bottleneck to global sustainable development. Africa's struggle is our struggle.” as the editors of this volume eloquently put it.

The central organizing idea that the editors use for this volume is that of duality- of the tension between jointly valuable but organizationally incompatible objectives. At the level of organizations, the typical poles of a duality are efficiency and effectiveness, revenue enhancement and cost efficiency, innovation and stability. At the level of national and regional policy, the duality this volume refers to is that between developing institutions and attracting capital.

Rules, procedures and norms for transparent and stable governance take time to build and require hard choices; attracting capital today creates pressures towards expediency. It is a very important tension and one that the organization designers in many developing economies (i.e. their policy makers) will recognize, beginning as they often do from a situation of significant "institutional voids". The tension in this duality seems pronounced in the African context because of the role of China as a source of investment that at best is agnostic to the development of local institutions and at worst, is suspected of aiming to keep them stunted. "If the water is too clear, you don't catch any fish”, as a senior Chinese administrator is reported to have said (pg 31). Shrill rhetoric from interested parties arrayed at the two poles of this duality seems to have, for too long, substituted for carefully collected evidence, creating an "evidentiary void" of its own.

The authors contributing to this volume help fill this "evidentiary void". This does not mean they agree on everything. We learn of cases where the prioritization of institution building over capital investment led to outcomes that can be classified as "politics beats economics". We also learn of situations where rapid infrastructure development has occurred, but at the risk of jeopardizing the long term viability of institutions.

The most practically relevant insights to emerge from this book may be around strategies for dealing with this duality. Organization science has pointed to three broad approaches to dealing with organizational dualities: structural separation (different parts of an organization pursue different poles of the duality), temporal separation ( the organization pursues different poles at different times) and what is known as "contextual ambidexterity" - finding ways to allow every organizational member to internalize the trade-offs and optimize it in a manner that benefits the organization. It is interesting to speculate whether these different strategies, in the context of the current problem, are best adopted by different stakeholders ( e.g. investors, multi-lateral funding agencies and national policy makers). 
The evidence and concepts that Gil, Stafford and Musonda have curated here can serve as a very useful platform to improve the quality of discussion and decision making around what is clearly one of the grand challenges for the world today. I congratulate them for putting this work together, and thank them for this valuable contribution to public discourse.

Phanish Puranam

Singapore, October 2018

Mahhamba Ndopfu

('The new dawn') 


\section{Duality by Design: The Global Race to Build Africa's Infrastructure}

\section{Nuno Gil, Ann Stafford and Inocent Musonda}

This book starts from the idea that there is much to learn about the design of new forms of organising, theoretically and empirically, by examining a phenomenon central to the global order: Africa's struggle to bridge a growing gap between supply and demand for basic infrastructure. A gap linked, amongst other factors, to the rapid growth of the continent's population, projected to reach forty percent of the world's population by $2100 .{ }^{1}$ Infrastructure is a vast class of long-lived, capital-intensive technologies that input into a wide range of productive processes that generate positive externalities and social surplus. Whether it is about transport - airports, railways and roads; utilities - power, water, sanitation and telecoms; or social assets - social housing, schools and hospitals, most infrastructures are common resources shared, in use, by many people and organisations. This is the fundamental attribute that makes infrastructure technology a source of broad value creation and appropriation. ${ }^{2}$ This attribute also explains the role of infrastructure technology in enabling economic growth, social development and in preparing societies for climate change. So it is incumbent on those who provide assistance to development, and on the African states themselves, to bridge the gap in basic infrastructure. Failure to act, and to make Africa a better place to live and work, will saddle future generations with a major bottleneck to global sustainable development. Africa's struggle is our struggle.

1 Africa's 2017 population is around 1.3 billion, 16.6\% of the world's population. The UN (2017) projects it will double into a quarter of the world's population by 2050; and by 2100 it will reach 4.5 million; together with Asia's population, projected to reach 4.8 billion by then, the two regions are projected to represent around $82 \%$ of the world's population

2 Frischman 2012 
In this book, we argue that there is a fundamental duality in the design of the interorganisational contexts set up to tackle this grand societal challenge of our times. Design dualities exist when organisations wish to pursue two objectives that are jointly desirable, but they struggle to reconcile the two because the organisational design attributes that underlie one objective tend to be incompatible with the attributes of the other objective. ${ }^{3}$ For example, whether to exploit or to explore; to integrate or to differentiate? Faced with difficulties in designing organisations to pursue dualities, organisational architects choose to focus on one of the poles, as opposed to pursuing both; so, they end up choosing 'gains from focus' at the expense of 'gains from ambidexterity'.

The empirical studies curated for this book focus on global efforts to promote socioeconomic development by ways of tackling Africa's infrastructure gap. They reveal a duality of building institutions and building infrastructure - two equally desirable objectives that turn out to be organisationally incompatible. Both institutions (the prescriptions created and used by humans to organize all forms of interaction ${ }^{4}$ ) and basic infrastructure (the technology needed for the functioning of a modern society) are key enablers of socioeconomic development. ${ }^{5}$ But building robust institutions is time-consuming and costly, and requires orderliness and transparency. In contrast, adaptability and opacity rule organisational design and evolution in order to enable quick development of new infrastructure. Faced with difficulties in reconciling these attributes, the interorganisational contexts set up to promote development choose to focus on either pole of the duality.

To make sense of this duality by design we need to attend to the newly emerging global order. China is rising to become the world's biggest economy, while the share of the global

3Lawrence and Lorsch 1967; Evans and Doz 1989; Birkinshaw and Gibson 2004; Smith and Tushman 2005; Gulati and Puranam 2009

4 Ostrom 1990, North 1990

5 To the extent that the Global Competitiveness Index framework of the World Economic Forum (2017) lists institutions and infrastructure as the first two pillars of basic requirements 
economy of the advanced economies, hobbled by fiscal pressures and populism, shrinks. This shift has given African states agency to pursue assistance to development by choosing between two groups of institutional intermediaries - the development agencies that broker resource exchanges between the recipient country governments and primary donors (taxpayers) and for-profit contractors ${ }^{6}$. 'Traditional' intermediaries include multilateral organisations such as the World Bank and the development agencies that are fully owned by the advanced economies; the 'emergent' intermediaries are associated with the economic rise of China. Chinese assistance to the development of Africa already equals that disbursed by the World Bank and dwarfs the assistance to development disbursed by the advanced economies. Irrespective of the intermediary, the unifying system goal is the same socioeconomic development. Yet, the priorities for action differ. In the interorganisational contexts enabled by traditional credits, the emphasis is on building institutions, but this emphasis shifts to infrastructure building when the Chinese credits are involved. And since the design attributes underlying the two objectives are incompatible, the interorganisational contexts choose to focus on the objective that is better aligned with the priorities of the organisational participants.

The choice of focus is rooted in differing preferences of the intermediaries and in the self-interests of the recipients. Traditional assistance to development is conditional on both western ideals of 'good' governance - transparency, accountability, inclusiveness, equity and the rule of law; and on the idea that development projects, the typical form to disburse assistance as it gives the intermediary leverage over inputs and activities, need to be delivered on time and within budget. But disbursing assistance under these institutional constraints is protracted because it requires mitigating many institutional voids in the environment. These

${ }^{6}$ Martens 2005; McDermott, Corredoira and Kruse 2009; Mair, Marti and Ventresca 2012; 
voids correspond to the absence, or underdevelopment, of the institutions of capitalism that are known to support socioeconomic activity in advanced economies, eg efficient markets, strong regulation, independent judiciary, property rights and contractual enforcement mechanisms ${ }^{7}$. So, under this approach, the design and evolution of the interorganisational contexts set up to build infrastructure are guided by the principles of orderliness and transparency; that is, building the institutions first, and build the infrastructure second. In contrast, Chinese assistance is not tied to governance and project management ideals, and so comes with limited conditionality. ${ }^{8}$ The Chinese approach takes the local environment as a given and does not seek to change it. Instead, the aim is to fast-track new infrastructure development by exploiting those institutional voids, or artfully manoeuvring around them. With his model, the principles of adaptability and opaqueness rule choice in organisational design and evolution, and results in building infrastructure first, building institutions second.

By foregrounding this duality by design, we are not suggesting moral equivalence or the abandonment of principles entwined with the traditional approach. And neither are we suggesting that one approach is 'superior' to another. Far from it. Indeed, we find equifinality in that both forms of organising are pursuing a similar system goal - socioeconomic development. Furthermore, we need to appreciate that the rise of a 'new' approach reflects the failure of the 'old' one to deliver. In fact, we still know little about how to organise for tackling grand challenges when there is a shortfall of institutions. What we are doing here is uncovering a duality that explains empirical regularities. We believe this duality offers a foundation for building novel theory of organisational design to navigate institutional shortcomings.

${ }^{7}$ Khanna and Palepu 1997; 2010; of course, customary rules and traditions are also 'institutions' that play an important role in structuring human interactions; how they complement the institutions of capitalism at the basis of advanced economies is a debate for another place

${ }^{8}$ Henderson 2008, Henderson, Appelbaum and Ho 2013 
But we are getting ahead of our story. We turn first to summarise the infrastructure gap facing Africa, and introduce our cognitive lens to further our understanding of how to tackle this grand societal challenge. We then offer an overview of our empirical findings and the book structure. Finally, we sketch the rudiments of a theory of (meta-)organising in environments with weak institutions, in light of the design duality revealed by this volume of studies on efforts to build basic infrastructure in Africa, a critical part of our global commons.

\section{Africa's Infrastructure Gap: A Grand Challenge of our Times}

Africa is the last frontier in management research ${ }^{9}$. So it is not surprising, then, that the continent's struggle to bridge its infrastructure gap, while long a topic of interest to development economists, remains a largely untapped problem in management scholarship. Yet Africa's infrastructure gap is a useful setting to produce fresh evidence and insight into new forms of organising to tackle the grand societal challenges of our time: Seemingly intractable problems that, in the way they intertwine technical and socioeconomic elements, cannot effectively be addressed without coordinated and sustained effort from multiple actors. $^{10}$ Management literature suggests that tackling grand challenges requires unconventional approaches and novel ideas. But we still know little about how to design these actionable solutions, even more so when there is a shortfall of institutions.

The root cause of Africa's growing gap in basic infrastructure is well understood: a conflation of rapid population growth, fast urbanization, climate change and a complicated colonial legacy. Assessments of this gap, estimated in monetary terms at \$130-170bn per year, with a related financing gap of $\$ 68-108 \mathrm{bn}$, are plentiful in the technocratic literature. ${ }^{11}$

${ }^{9}$ Klingebiel and Stadler 2015; George et al 2016

10 Some grand challenges are discrete with a clear endpoint, like developing a HIV vaccine; others are broad and open-ended like building Africa's infrastructure, curing cancer, or eliminating poverty; Colquitt and George 2011; Ferraro, Etzion and Gehman 2015

${ }^{11}$ African Development Bank 2018 
It is useful to share some illustrative figures before introducing our core argument on tackling this grand challenge. For example:

- The International Energy Agency estimates that nearly half of Africa's population lack access to grid-connected electricity, and that the frequency of power outages experienced by industrial users costs about two percent of the continent's GDP ${ }^{12}$.

- According to the UN, economic water scarcity is a widespread problem in subSaharan Africa, while physical water scarcity is problematic in Northern Africa.

- The proliferation of slums is reason for global concern - $60 \%$ of sub-Saharan Africa's urban population live in slums, lacking property rights and access to very basic public infrastructure and services ${ }^{13}$. With $90 \%$ of urban growth happening in the developing world, particularly in Africa, the UN projects that by 2023 the number of slum dwellers will reach two billion (a quarter of the world's population). If the world fails to act, this will fuel poverty, social exclusion, radicalization, hunger, gender inequality, and mass migratory pressures; all of which threaten the global order.

- Equally worryingly, by 2100, Africa will host many of the largest megacities in the world. Metropolis such as Lagos, Kinshasa, Dar es Salaam, Khartoum and Niamey are all projected to exceed 55 million people ${ }^{14}$.

So it is not surprising that the UN asserts that investment in basic infrastructure is the largest share of the needs to meet the Sustainable Development Goals (SDGs). These goals include ending all forms of poverty, fight inequalities, protect the planet, tackle climate change and ensure prosperity. And the ninth goal of the SDG, in particular, spells out the need to build resilient, reliable and sustainable infrastructure, with a focus on affordable and equitable access for all. Importantly, a 1\% increase in the stock of basic infrastructure is expected to correspond to a $1 \%$ increase in GDP. ${ }^{15}$

12 IEA 2016; IRENA 2014

${ }^{13}$ UN-Habitat 2016; UN 2018

${ }^{14}$ Hoorweg and Pope, 2017.

${ }^{15}$ UN 2013; World Bank 1994; Esfahani and Ramirez 2003 
With this backdrop, we turn now to examine the challenge through an organisational lens.

\section{Institutional Voids, Intermediaries and Organising for Development}

At the crux of the challenge of promoting development by way of tackling Africa's infrastructure gap is the problem of navigating institutional voids. Institutional voids relate to the lack of developed prescriptions to organise interaction between humans and economic agents; institutions are interdependent with norms, but the two concepts are distinct. Norms are the cultural prescriptions that are part of the generally accepted moral fabric of societies. In contrast, the best way to think of institutions is in terms of the 'rules of the game' that individuals and organisations design, both formally and informally, to enable and constrain collective and individual action. Broadly, these rules encompass three dimensions:

- They clarify who the participants are in a set of interactions, their distinctive roles and how to achieve the superordinate goals that unify the participants.

- The arrangements that monitor interactions between participants within an organisational system and with external stakeholders, as well as the arrangements that are used to assess the performance of the system in relation to the identifiable system goals.

- The arrangements by which the consequences of noncompliance are clarified, how conflicts between participants and external stakeholders are adjudicated, and how penalties for noncompliance enforced.

In developing countries, the underdevelopment or absence of the institutions of capitalism, taken for granted in advanced economies and which enable and support socioeconomic activity, creates institutional voids ${ }^{16}$. Institutional voids hinder the mechanisms that allow resource exchanges, increasing the transaction costs for businesses and the state. These voids include:

\footnotetext{
${ }^{16}$ Khanna and Palepu 1997, 2010
} 
- Inefficient markets for capital, skilled labour and products.

- Poor and underdeveloped regulation.

- Ill-defined property rights.

- Weak systems of checks and balances; the so-called non-executive institutions of accountability, capable of constraining arbitrary action by the political leadership and the public bureaucracy.

- Weak rule-of-law and independent judiciary to act as impartial third-party structures to arbitrate interorganisational conflict, enforce legal contracts and resolve disputes.

- Absence of competitive, free and fair elections.

- Limited openness in the way the civil society operates, and information flows, due to institutional constraints imposed on media and freedom of information.

- Emphasis on the conferral of patronage in the way political parties are organised.

Gaps in basic infrastructure are in themselves a class of physical or 'hard' institutional voids that are challenging to navigate. A lack of transport infrastructure complicates the flow of goods and people, making it harder for individuals and organisations to coordinate action, cooperate and trade; unreliable power supply deters private investment and undermines productivity; lack of basic social infrastructure makes it harder to develop and retain talent and so build local capabilities. And yet, each of these basic infrastructure voids holds opportunities for multiple public and private actors to work together to create and appropriate value. Basic infrastructures are common goods that can be leveraged to promote societal prosperity at large. And new infrastructure developments create lucrative opportunities for private firms, as either suppliers or development partners. But regrettably, corrupt actors also see in new infrastructure development projects opportunities for rent seeking by breaking the law or circumventing ambiguity in weak institutions and pursuing informal private gains at the expenses of the common good.

Of course, Africa is not a homogeneous continent. Around a half of African states have already achieved middle-income status, and in many others, a democratic central government 
has devolved power to local authorities ${ }^{17}$. Still, institutional voids remain a feature of most African states; settings where deep-seated aspects of neo-patrimonial governance enable the local elites to concentrate vast amounts of political, economic and, even, juridical and military power. ${ }^{18}$ Helping African states and private firms navigate these institutional voids are the intermediaries. In the infrastructure sector, development agencies play this role by brokering resource exchanges necessary for the authorities to build capital-intensive public goods. This is to the extent that assistance to development as a source of revenue is roughly 10\% of GDP for emerging economies. These intermediaries fall into two categories.

The 'traditional' intermediaries provide about two-thirds of assistance to development, which includes development agencies owned by the advanced economies and multilateral agencies such as the World Bank ${ }^{19}$. These traditional intermediaries make assistance conditional on the recipients conforming to western standards of 'good' governance and project management ${ }^{20}$. If the recipients fail to meet these conditions they cannot qualify for assistance, or the development agencies apply pressure, ie threatening to terminate assistance, actually terminating it or reducing it. In other words, traditional agencies act as open-system intermediaries that seek to both create benefits for parties beyond a restricted set of system participants, as well as to improve the general institutional environment. ${ }^{21}$

17 African Development Bank 2014. African Development Bank Group Strategy for addressing fragility and building resilience in Africa. Abidjan, Cote d'Ivoire

${ }^{18}$ Chabal and Daloz 1999; Erdmann and Engel 2006

${ }^{19}$ OECD 2014

${ }^{20}$ Good governance is part of a broader set of prescriptions on how to engineer development that became known as the 'Washington consensus' in the early 1980s. Other prescriptions include a neoliberal agenda of economic reform promoting less government, the benefits of markets, and the importance of avoiding excessive inflation, excessive budget deficits, and overvalued exchange rates. The Washington Consensus has since lost its allure, but assistance to development by traditional donors remains conditional on good governance; UN 1995; Burnside and Dollar 2000; Hermes and Lensink 2001; Rodrick 2006

${ }^{21}$ Mair and Marti 2009; Dutt et al 2016 
The other third of assistance to development comes from the 'emerging' intermediaries — the countries that lie outside the OECD Development Assistance Committee. China bears by far the greatest weight in this group. Assessing assistance disbursed by China - as opposed to pledges of assistance yet to be committed - is difficult, as the Chinese authorities are very secretive. But, reliable figures suggest that assistance from China in Africa will soon exceed assistance disbursed by the World Bank; Chinese assistance also dwarfs that from western agencies. ${ }^{22}$ Assistance provided by intermediaries such as the China Eximbank and the China Development Bank comes with limited conditionality ${ }^{23}$. This is not to say, though, that the Chinese intermediaries act as closed-system intermediaries, only seeking benefits for the participants in the interorganisational contexts enabled by Chinese credits. This is not the case. Instead, Chinese assistance seeks to replicate the successful model of Japanese assistance to develop China decades earlier, and so the Chinese loans tend to be tied only to purchasing and importing from China as much technology and services as possible.

Much was written in the economic development literature of the last decade about how, with the economic rise of China, African governments have gained agency to choose between two competing forms of intermediation. ${ }^{24}$ Before we develop our argument from an organisational perspective, we summarize here the gist of this unresolved debate: On one side are scholars who see Chinese assistance as allowing profligate African states to build up unsustainable levels of debt, retain weak financial, economic and political governance, and occasionally infringe human and civil rights. For harsher critics, Chinese assistance is nothing more than a 'narrow elite business dialogue' and 'rogue aid', serving an opaque clique of

\footnotetext{
${ }^{22}$ From 2000 to 2015, 63 billion USD were disbursed by the Export-Import Bank of China (China Eximbank) against 1.7 billion USD by the USA Eximbank; in 2015, the World Bank provided US\$14.3billion of loans to Africa, a figure similar to the finance committed by China; Eom et al 2017

${ }^{23}$ Henderson 2008; Henderson, Appelbaum and Ho 2013

${ }^{24}$ Hernandez 2017; van Dijk 2009; Woods 2008; Tan-Mullins, Mohan and Power 2010
} 
interests dominated by informal and personal relationships. ${ }^{25}$ China's true motives for cooperation with Africa are also questioned, particularly around the use of natural resources as collateral in return for credit, the so-called 'resource for infrastructure deals'.

Yet other scholars argue that China-bashing is hypocritical and only serves to bolster western interests. They claim that western assistance to development is dogmatic and inflexible, that good governance requirements increase transaction costs too much and that western assistance's impact on socioeconomic development has been negligible. And so, in their view, China provides much-needed investment in critical infrastructure; bringing technical and commercial know-how and widening market access; and quickly completing new infrastructure necessary for development without tiresome strings attached. Disagreements notwithstanding, there is agreement that the availability of alternative sources of credit has strengthened the bargaining power of African states in their negotiations for assistance to development. This gained agency raises the question if a 'race to the bottom' will ensue in the conditions offered to borrowers who are of strategic importance to both groups of intermediaries ${ }^{26}$.

\section{Using Design to Navigating Institutional Voids}

The debate among development scholars on the new global order in which we live is instructive, but leaves outstanding important issues from an organisational design perspective. Broadly speaking, intermediaries enable forms of meta-organising, ie enable public agencies and private firms to come together in actor-networks unified by an identifiable system-level goal ${ }^{27}$. But environments with poor institutions are a boundary condition that lies outside most extant organisational design studies. Hence, our

\footnotetext{
${ }^{25}$ Naim 2007

${ }^{26}$ Mohan and Lampert 2013; McLean and Schneider, 2014

${ }^{27}$ Gulati, Puranam, Tushman, 2012
} 
understanding remains incipient on the choices that organisational designers need to make to navigate institutional voids. To further our understanding of this issue, we first need to amass evidence in the tradition of inductive research. Armed with data assembled through painstaking fieldwork, we can cycle between more data and theory to identify relevant constructs, propose relationships that link those constructs and develop new underlying theoretical arguments on how those logic relationships illuminate general phenomena. ${ }^{28}$ So, empirical studies about Africa's struggle to bridge the gap in basic infrastructure are useful to help us sketch the rudiments of theory on organisation design to navigate institutional voids.

This volume of empirical studies reveals efforts to mobilize a diversity of organisational structures to bridge Africa's infrastructure gap: markets to address the lack of power generation capacity; authority hierarchies to develop new railway lines; strategic alliances to build new hospitals; self-organising structures to upgrade informal settlements; and other hybrid forms of organising. This diversity is not surprising. Indeed, it mirrors the diversity of designed structures by which advanced economies pursue similar goals. Given that the focal problems have differing attributes, it is predictable to find differing structures to economize on transaction costs and leverage local capabilities. ${ }^{29}$ Changing institutions is also costly and time-consuming, for example, contracting for property rights, and those transaction costs are a source of organisational diversity. ${ }^{30}$ Furthermore, African states are not alike from an institutional perspective, another factor contributing to organisational diversity. Grand challenge task environments also require both a high degree of differentiation to attend to the

\footnotetext{
${ }^{28}$ Eisenhardt, Graebner, Sonenshein 2016

${ }^{29}$ Williamson 1985; Ostrom 1990

${ }^{30}$ Libecap 1989.
} 
different facets of the tasks and a high degree of integration among the participants to achieve desirable outcomes — two attributes that also contribute to organisational heterogeneity. ${ }^{31}$

Our goal here, then, is not to explain this diversity of interorganisational structures to tackle Africa's infrastructure gap. Rather, we were driven by the question as to whether we could identify any general underlying patterns in the way these differing structures sought to navigate the institutional voids. Could we, then, dig below this diversity to identify patterns in the way these structures were designed to adapt to their environment? As we probed deeper into the evidence amassed for this book, a pattern did emerge. All the studies illuminate interorganisational contexts set up to ultimately promote socioeconomic development by way of tackling basic infrastructure gaps. Yet the evidence and the propositions advanced to explain the extent to which these contexts succeeded or failed to achieve their objectives suggest two different approaches to navigate institutional voids. One group of studies traces success or failure to the way the participants managed or not to fill the institutional voids. Another group of studies advances explanations for organisational success or failure that are rooted in the way the institutional voids were exploited.

But before we turn to our theory, and in the tradition of inductive research, here is an overview of the evidence collated across the next twelve chapters. The studies differ in that some verge more on technological aspects, whereas others focus on the institutional issues. Irrespective, though, of the cognitive lens deployed to guide data collection and analysis, all studies offer fresh evidence on organising to build basic infrastructure from transport and energy, to hospitals and social housing. As we worked to make sense of the findings, it dawned on us to organise this book by whether the focus was on building institutions or building infrastructure - a duality to which we return after presenting the findings.

\footnotetext{
${ }^{31}$ Knudsen and Srikanth 2014
} 


\section{Mitigating Institutional Voids by Design (Part I)}

Part I offers a set of empirical studies focused on interorganisational contexts enabled by traditional intermediaries. Symptomatic of the issues with an organisational focus on building institutions, the emphasis of most studies is on the struggle of these contexts to bridge the infrastructure gap that they are targeting. The delays are rooted in difficulties to build institutions and capabilities, and, thus, difficulties in building markets, polycentric structures and strengthening regulation.

Specifically, Chapter 2, by Worch et al, adopts a 'capability perspective' to explain failure to change and develop institutions. The authors ground their insights on the South Africa's electricity crisis between 2005 and 2008, when institutional difficulties to reform the state's monopolistic national electric utility, Eskom, led to multiple power outages. The institutional reform aimed to create a competitive market to attract private investment to develop power generation capacity, expand the distribution and transmission network, and ameliorate the coal supply chains. But the analysis reveals unintended consequences of the reform, such as a substantial loss of critical competences, skills and experience within Eskom, which merely exacerbated the energy crisis. The main insight is that institutional changes come with an added risk of letting an existing capability gap grow further, and, once lost, local capabilities are hard to regain because the gaps take time to identify and resolve.

Chapter 3, by Hamukoma and Levy, also focuses on institutional reforms as a prerequisite to fill infrastructure gaps. They, too, ground their insights on the South Africa energy crisis. They trace a six-year delay to implement the new energy policy to a conflict between powerful political stakeholders with diverging visions - an unresolved conflict exacerbated by the lack of dispute-resolution mechanisms in the environment. The study reveals difficulties to reconcile political interests that competed between letting the market set energy prices to attract private investment and keeping energy affordable to reduce poverty. 
The authors note that, in the end, 'politics trumped economics', leaving South Africa's power industry overwhelmingly vertically integrated and controlled by Eskom, the state-owned utility - and so, after all these years, the much sought institutional reform is yet to happen.

Karplus et al yield a similar insight in Chapter 4, on the institutional enablers of energy system transition. Their research is grounded on the expansion of solar photovoltaic power capacity in eight African countries. The analysis reveals that institutional voids, if successfully navigated with the help of institutional intermediaries, are not always impediments to technological progress. For example, development agencies can substitute for lack of capital markets, or a market reform can overcome vested interests in the status quo. But the authors also note that seizing technological opportunities in sustainable ways requires institutional reform in order to enable efficient markets and competitive procurement - and, as their evidence shows, these institutional reforms take a long, long time to implement.

Chapter 5, by Rose et al, picks up on the problem of ameliorating existing institutions to make them effective. The authors ground their argument on the Southern African Power Pool (SAPP) - the oldest and most advanced electricity market in Africa. Their research shows the SAPP has the potential to enable resource-rich countries to export power to countries with limited resources, and so improve security of supply for participants and reduce the cost of providing reserves. But, 20 years after its inception, the SAPP still struggles to encourage capital investment and reform of national policies because the participants cannot agree the design of contracts, and the transaction costs remain too high. Difficulties in integrating effort are traced to the lack of a cross-border body with authority to harmonize national regulations and policies, whilst deferring implementation to the states. The authors conclude by suggesting that a more polycentric structure could encourage cooperation to agree decisions on investment priorities, but its creation is hampered by a gap in local capabilities. 
Adopting a technological perspective, Chapter 6, by Ismail, Metcalfe and McPherson, argues that innovation is creating new opportunities to fill infrastructure gaps. But the authors also recognise that institutional reform is a prerequisite to seize those opportunities. Their study focuses on Zambia's growing gap in power generation capacity, due to population growth and climate change. The analysis points to hybrid technological paths, which combine capital-intensive technology, eg large-scale solar and wind generation, with decentralised solutions, eg off-grid solar. But implementing this idea requires setting up a hybrid system capable of concomitantly navigating different sets of institutional voids. The authors suggest working both with traditional intermediaries to promote decentralised solutions and with emergent intermediaries geared to capital-intensive developments - an idea, therefore, that overcomes the organisational incompatibility that underlies the two poles of the duality.

Chapter 7, by Hellowell, looks into a different organisational structure — strategic alliances between the public and private sectors, so-called public-private partnerships (PPPs). The author grounds his study on a PPP contract for a new hospital and a range of core clinical services in Lesotho — a form of organising much promoted by the western intermediaries. The analysis illuminates how capability gaps got in the way of equitable distribution of value. Specifically, the study reveals how a PPP, once labelled 'the future of healthcare delivery on the African continent', became a major source of budgetary uncertainty and a demanding pull on the government's scarce resources. Hellowell traces difficulties in ensuring an equitable distribution in value appropriation back to a failure to first build the state's contractual capabilities.

Along the same lines, Chapter 8, by Stafford, Stapleton and Agyemin-Boateng, reveals the urgency to improve PPP governance. The study looks at five PPPs in Ghana, a country that ranks in the top half on measures of good governance in Africa. Yet the study reveals that to accelerate much-needed infrastructure developments, some PPPs have exploited 
institutional voids to circumvent transparency in the processes of project choice and public procurement, or to renegotiate contracts in dubious ways. Their findings leave it unclear if the long-term value of the public goods will outweigh the short-term public losses. But, as the authors claim, without improvements to increase accountability, eg creating independent agencies staffed with a small group of well-paid technocrats, the situation is unsustainable.

The focal problem informing the last two chapters in this section is the growth of informal settlements. Here, the beneficiaries of aid are the poorest of the poor, and because investments are non-revenue generating, solutions cannot be found in market forces. In Chapter 9, by Nadim, the effectiveness of self-governance is contrasted with failed centralised approaches. The study is grounded on efforts to fill gaps in affordable housing in Greater Cairo, Africa's largest city by population. The analysis shows that centralised approaches undertaken by an authoritarian state produced many 'ghost cities' by ignoring the needs and interests of the poor. In contrast, self-governance enabled the poor to build informal mixed-use buildings, combining residential and work uses — a sustainable, flexible model of zero-commuting housing. But the study does not suggest that self-governance is the solution: informal settlements remain a cause of extreme poverty and social inequality.

This section concludes with Chapter 10, by Gil and Macaulay, where the authors introduce the idea of collective action under the shadow of contractual governance. The research is grounded on a participatory approach to upgrade informal settlements in Greater Cairo. The analysis reveals how multiple resourceful actors - state, donors, intermediaries, suppliers and NGOs - forged a set of legal contracts to upgrade informal settlements. Contractual governance was then leveraged to grant the poor decision rights in resource allocation. The study shows this hybrid structure succeeds in encouraging mutual trust and norms of cooperation to flourish, a prerequisite for the poor to volunteer their knowledge, time and effort - informal resources much needed to identify real problems and co-produce 
sustainable solutions. Another advantage of this structure is to economize on the transaction costs that would otherwise be necessary to resolve the ill-defined property rights of the poor. But questions remain if this hybrid structure can be scaled up and remain effective.

We turn now to summarise the empirical findings at the other pole of the duality.

\section{Exploiting Institutional Voids by Design (Part II)}

The second part of this book offers a collection of empirical studies on interorganisational contexts formed to tackle Africa's infrastructure gap, as enabled by Chinese credits. Some studies document the rapid development of new railways, while others illuminate organisational struggles and failures in efforts to fast-track new infrastructure developments. In all cases, though, there is limited effort to change the institutions in the environment and no certainty of the sustainability of the technological public goods.

Specifically, Chapter 11, by Wissenbach, argues that designing a powerful, centralised organisational structure to fill an infrastructure gap is a double-edge sword. Wissenbach grounds his insights on the $475 \mathrm{~km}$ long railway line linking the port of Mombasa to Nairobi an infrastructure built by the Kenyan state with Chinese assistance, initially designed as part of a broader railway network to boost transport capacity in the East Africa region. The analysis traces the development of the railway line in a record four years to a hierarchical authority controlled by the President of Kenya. This centralised structure had capability to unilaterally resolve disputes, adapt to uncertainty, mobilise state resources quickly and circumvent problems due to ill-defined property rights. But the high speed in getting things done was achieved at the expense of transparency, accountability, probity and equitability in value allocation. It also remains unclear if the railway will ever catalyse broader benefits, since a centralised approach failed to encourage collaboration and coordination with the neighbouring countries. 
Chapter 12, by Musonda et al, offers a more optimistic tone on the concomitant risks and opportunities that derive from 'looking east'. The authors ground their claims on a comparative study between two cases: the Gautrain rapid rail in South Africa, the continent's first rapid rail system, and the Addis Ababa light rail in Ethiopia. The first case illustrates a structure by which a democratic state leveraged an emerging market to form a strategic alliance with a private firm — in line with western standards of good governance. The second case illuminates how an authoritarian state entered into a strategic alliance with Chinese state-owned companies under opaque conditions. It is too early to tell if the public goods produced by both contexts will be sources of long-term value creation, but evidence, so far, suggests that both partnerships are creating broad societal value. Clearly, though, the statestate approach enabled by Chinese credits is only available to authoritarian states. But if this approach does succeed in boosting economic growth and social development, then, conceivably, the option is open for the recipient state to adopt more transparent western-style approaches when they seek to tackle other gaps in basic infrastructure in the future.

Chapter 13, by Gil and Pinto, concludes this section by anticipating the thesis advanced in this book. The authors ground their research on a sample of four interorganisational contexts formed to fill gaps in very basic transport infrastructure in Nigeria and Uganda; two contexts are enabled by traditional intermediaries and two by Chinese intermediaries. Their research shows that in the contexts enabled by the World Bank, building institutions is prioritised to the detriment of new infrastructure development. When the intermediary is a Chinese actor, the priorities are reversed. Underlying this choice are design attributes that are organisationally incompatible: transparency and orderliness rule as guiding principles when the focus is on building institutions; adaptability and opaqueness rule when the focus is on new infrastructure development. Crucially, the four cases show that gains from whichever focus may be insufficient to achieve the system-level goal, socioeconomic development. 


\section{Duality by Design: Between Building Institutions and Building}

\section{Infrastructure}

The idea that institutional voids can be navigated in different ways is not new. We know that institutions are more than just background conditions; institutions directly influence strategic choices available to an organisation, and organisations are known to achieve and sustain competitive advantage through strategies that overcome, shape and capitalise on the nature of their institutional environments. ${ }^{32}$ Furthermore, studies of firms entering in emergent markets show some organisations see institutional voids as 'opportunity spaces', which they choose to strategically exploit or overcome. ${ }^{33}$ Other organisations see the very same institutional voids as constraints to mitigate first, before taking any further action ${ }^{34}$.

Yet we still know little about how choice between differing approaches to navigate institutional voids affects the organisational design choices to navigate those voids. We can expect, though, the two sets of choices to be interdependent, since organisation design is contingent on the institutional environment to which the organisation must relate. ${ }^{35}$ So a choice between intermediaries that espouse differing principles to navigate institutional voids is, necessarily, a choice between differing organisational designs to relate the intermediated systems to their intermediaries. In other words, a choice between competing systems of intermediation is a choice between interorganisational contexts with differing architectures in terms of their system components, their relationships to each other and the environment, and the underlying principles that guide organisation design and evolution. ${ }^{36}$

32 Khanna and Palepu 1997, 2010; Henisz, Dorobantu and Nartey 2014; Khanna and Rivkin 2001

\footnotetext{
${ }^{33}$ Mair, Martı and Ventresca 2012

${ }^{34}$ Doh et al 2017; Luo and Chung 2013; Pinkham and Peng 2016

${ }^{35}$ Lawrence and Lorsch 1967; Thompson 1967; Scott 1981

36 Simon 1981; Fjeldstad et al 2012
} 
In agreement with these precepts of organisation theory, the body of evidence curated for this book is suggestive of an organisational duality. In the group of interorganisational contexts enabled by traditional credits, the system should evolve step-by-step and engage openly with government at different levels and within the legislative environment. These principles also offer a basis to evaluate organisational performance. That is, the difficulties to implement these principles explain delays, cost overruns, and other forms of organisational failure. In marked contrast, underlying the design and growth of the interorganisational contexts enabled by Chinese credits are the principles of opaqueness and adaptability. Engagement with stakeholders is seen as an unnecessary source of confusion and delays, and adaptability is regarded as desirable to enable quick capital investment towards new infrastructure development with limited planning a priori. For the participants, high performance hinges on getting the new infrastructure done quickly, which restricts efforts to build institutions to only those institutions that need to evolve in order to ensure the infrastructure can function and is sustainable.

If we accept that these two forms of organising are pursuing objectives that are jointly desirable — and, we argue, they are — the empirical studies here show that these two objectives are organisationally incompatible. The two objectives are hard to reconcile because the design attributes that underlie one pole of the duality cannot be reconciled with those of the other pole. And consistent with predictions of organisational theorists, the organisational designers choose to focus on only one or other of the poles of the duality. ${ }^{37}$

We turn now to examine in more detail the choices at each pole of this duality.

${ }^{37}$ Gulati and Puranam 2009; Birkinshaw and Gibson 2004; Smith and Tushman 2005 


\section{Organisational Design to Mitigate Institutional Voids}

The choice to focus on building institutions in the pursuit of development is rooted in western scholarship on the contribution of institutions to economic growth and market development. This large body of literature traces economic growth to the way evolution in institutions has allowed states to credibly commit to uphold property rights, to the quality of the rules governing economic exchange, and governing how these rules are enforced and may be changed. From this perspective, other key markers of modern societies are the separation of policy interests from the personal economic interests of the elites, and the quality of regulation. ${ }^{38}$ These ideas as a whole apply pressure on traditional intermediaries and recipients of assistance to extensively carry out tasks associated with planning, cost-benefit analysis and design before allocating capital, procuring suppliers and transforming designs (the instructions by which we can get things done) into usable technological artefacts. Furthermore, the participants in the contexts enabled by traditional credits must ensure that value creation goes beyond the private value appropriated by the restricted set of participants.

An organisational system that fails to meet these principles compromises its ability to claim positive performance and legitimacy because it fails external validation relative to the norms that western actors deem appropriate. Hence, if the recipient state lacks regulation to acquire private resources, eg land and supplier capabilities, this void needs filling first, in a fair and transparent way, before the organisational system can grow further. If the state lacks local capabilities to write and administer contracts to govern buyer-supplier relationships and public-private partnerships, organisational evolution becomes contingent on building these local capabilities first. Engaging with stakeholders is also a prerequisite to encourage norms of cooperation to flourish; setting up efficient markets pre-empts illegal activity, and projects

38 North and Weingast 1989; North, Wallis and Weingast 2009 
are expected to keep the scope stable, and be delivered on time and within budget. $^{39}$ So, under this approach, filling the institutional voids has priority over infrastructure building.

Implicit here is the acceptance, socially constructed, that socioeconomic development is a slow process. And so, accordingly, the time that elapses between identifying an infrastructure gap and allocating capital to bridge that gap is ruled out from performance evaluation. What matters here is that growth is orderly and transparent. A substantive delay in allocating capital - to the extent that the focal infrastructure gap widens rather than shortens before the capital is invested - is not a failure per se. Rather, this outcome is attributed to exogenous factors that prevent the adoption of tried and tested forms of organising in advanced economies to develop similar technologies. In other words, a failure to develop infrastructure is attributed to a failure to build local institutions and capabilities, not to a failure of this form of organising to navigate the institutional voids in the environment.

\section{Organisational Design to Exploit Institutional Voids}

The sense that the organisational choices espoused by the traditional intermediaries are at odds with the urgency to fill Africa's infrastructure gap has encouraged African governments to 'look east' in their search for other actionable solutions. With the economic rise of China and its approach to foreign policy, epitomised by its Belt and Road Initiative, African states gained agency to choose between alternatives. The fact this edited collection offers a smaller number of empirical studies on interorganisational contexts enabled by Chinese credits is irrelevant from a theoretical perspective. Our purpose here is not to test the statistical

39 Professional project management norms are still rooted in classic scholarship that associates high performance to stable scope, budget and schedule (Morris 1994; Flyvbjerg et al 2003). But these ideas have been refuted on the basis that they underestimate interdependencies between projects and the environment (Miller and Lessard 2000; Lenfle and Loch 2010). More recently, scholars have suggested that performance assessments need to account explicitly for whether slippages in targets add or not opportunities for broad value creation (Gil and Pinto 2018; Love and Ahiaga-Dagbui 2018; Lavagnon, 2018) 
significance of our insights, but instead illuminate a duality in designing organisations to navigate institutional voids. Furthermore, the lack of transparency in the decision-making that guides organisational choice in contexts enabled by Chinese credits is a real obstacle to negotiate access to these research sites.

When the focus is on exploiting institutional voids - or overcoming them by avoidance through artful manoeuvring - organisational growth is opaque and adaptable. By rejecting western governance ideals, or any sense of a moral mission to change the ways Africans live, the emergent intermediaries win the political favour of the sovereign-conscious states ${ }^{40}$. By limiting their engagement with external stakeholders, the organisational designers opt for narrow searches for solutions to focal problems, trading off less exploration for quick stability in the solution for the focal problem. Bluntly stated, the idea here is not to tackle a grand challenge in innovative and cooperative ways; these contexts are not designed to cope with turbulence and complexity in the stakeholder environment, but rather discount the importance of stakeholder acceptance and of enlisting stakeholder support for any proposed solution. Instead, the objective here is to quickly mobilize resources in order to build a new infrastructure. And, of course, it would be disingenuous not to recognise the opportunities that such an approach creates for informal private gains for the political leadership and public bureaucracy - on both sides of the bilateral arrangements.

This organisational choice centralises decision-making authority in a tight-knit coalition of actors involving the state, the intermediary and private firms chosen by the intermediary. Such centralised structures exploit weak institutions governing the acquisition of private resources to fast-track organisational growth. Price setting happens, not through the market, but through opaque decision-making processes. Engagement of stakeholders in planning and cost-benefit analysis is restricted in order to move quickly to implementation. Improvisation

40 Tull 2006; Brewer 2008 
and ingenuity are then employed to eliminate any bottlenecks that may emerge along the way. These contexts are not, then, constrained by accountability pressures: budgets and timescales are negotiated and renegotiated behind closed doors; participants act without pressure to justify slippages in cost and schedule targets; and the lack of local capabilities is circumvented by importing capabilities from outside markets. Performance is tied to the speed by which the infrastructure gets built and to the extent to which the context succeeds to build the institutions that are strictly necessary to operate the new infrastructure.

Importantly, though, the evidence here suggests that there is no guarantee that a context designed to exploit institutional voids in order to quickly build an infrastructure can meet this objective. For example, institutions protecting property rights and customary rights may be fragile, but they can still get in the way and stall organisational growth. This is often the case with efforts to compulsorily acquire land. Often, the land is protected by customary tenure regimes structured around tribal, clan or village entities, as well as by an incipient legal framework and judiciary system left behind by the colonialist ${ }^{41}$. And landowners will not, therefore, part ways with their land without first putting up a major fight. Organisational growth may also be stalled by difficulties to pay back the loans due to poor planning. So this approach to organising may fall foul of the very same institutional voids that it seeks to exploit.

Complicating matters further, even when a centralised and authoritarian approach succeeds in quickly building an infrastructure, it remains unclear if it has created value beyond the private value that was appropriated by its participants. Which does not mean this design choice cannot create common goods. It can. But because stakeholder engagement is

${ }^{41}$ Less than 10 per cent of the African land estate is subject to formal entitlement; Wily 2011 
limited and decision-making is opaque, it is harder for third parties to see if the outcomes are a source of broad value creation or not. Exacerbating the difficulties in evaluating performance is an attribute of the system goal itself: infrastructures are long-lived assets that operate enmeshed within the environment. If demand for a new infrastructure does not materialise straight away, it does not mean that demand will not pick up later on. Furthermore, a new infrastructure may not be financially self-sustainable, but it can still be a source of value creation if it catalyses economic growth and social development. More theoretically, any capital investment in a new basic infrastructure works like a real option in that it creates the right, but not an obligation, to take an action at a price - the exercising cost - in the future. ${ }^{42}$ New transport infrastructure creates opportunity to access and build new markets; new power plants create an environment for accommodating economic growth; water desalination plants safeguard against climate change, and so on. There is, of course, uncertainty about when and if these scenarios will realize, and on the cost of exercising the option, which loads uncertainty on whether the capital investment will ever pay off. But if the infrastructure is not there, no option is open to create value if the uncertainties resolve favourably in the future.

But, there is a catch. Building and maintaining infrastructure is not free. It requires setting up a costly interorganisational context that uses resources that could otherwise be allocated to tackle competing needs. When the needs are many, a question arises about priorities. If strategic planning is rushed, information flows are hidden and decision-making is opaque, the leaders who sanction the investments are asking third parties to put their faith in the good judgement of these leaders - assuming that these leaders care about third parties. Third parties may be willing to give the leaders the benefit of the doubt, even amid rumours of corruption and bribes, if the state is not too fragile; that is, if the state remains

\footnotetext{
${ }^{42}$ Trigeorgis, 1996; Gil, 2007, 2009
} 
fundamentally able and willing to operate in the public interest, albeit with weak institutions. ${ }^{43}$ Such environments, for example, are not dissimilar to those that surrounded infrastructure development in the nineteenth century in the US. ${ }^{44}$ But trusting leaders is hard if state fragility is very high: settings with high levels of conflict and instability in political and economic life, and where the lack of basic bureaucratic capacities leads to a fundamental disregard for the rule-of-law and a lack of public services. In these settings, policy decisions and the personal interests of local elites closely intertwine. Under these circumstances, expecting third parties to give the leaders the benefit of the doubt is asking too much.

\section{Towards a Theory of Designing Organisations for Development}

Taken together, our insights reveal an important duality in designing organisations to pursue development by means of tackling gaps in basic infrastructure. On one pole of the duality are interorganisational contexts that choose to focus on building institutions before building the infrastructure. The degree to which these contexts succeed in building the infrastructure varies, and progress is invariably slow. Yet the delays are attributed to difficulties to build the institutions and not to the choice of focus. In other words, it is not the design choices that are inadequate, but rather that it takes time to build institutions. And at the other pole is an organisational design choice that takes the institutional environment as it is, and, indeed, takes advantage of weak institutions in order to pursue quick infrastructure building. Our findings also suggest substantive variation in the extent to which these contexts are successful in building the infrastructure and the institutions necessary for its functioning

Strikingly, this duality invigorates a debate that is central to the development literature, and has been unresolved for decades: Albert Hirschman's seminal idea that assistance to

\footnotetext{
${ }^{43}$ State fragility research comes from efforts in the development literature to understand how the world's least developed countries, such as Somalia and Sudan, differ from developing countries that seem to be advancing much more rapidly, such as Mexico and China; Collier 2009; Marshall and Cole 2008

${ }^{44}$ Levy 2014; Chandler 1977
} 
development should put less emphasis on planning activities to undercut the propensity of the borrowers to underestimate their own ability to tackle all the difficulties and troubles that future events may bring ${ }^{45}$. Hirschman claimed that had it not been for a lack of awareness of the difficulties encountered in the course of many development projects — the 'hiding hand' principle - people would not have embarked on those projects, as they would not have been viewed as feasible. In other words, Hirschman suggested a 'bias for hope' could be advantageous to induce action through error in institutionally underdeveloped settings. As he put it, 'the hiding hand does its work essentially through ignorance of ignorance, of uncertainties, and of difficulties' (Hirschman 1967 p. 35). Furthermore, he challenged the value of conditionality tied to assistance disbursed by the traditional intermediaries, claiming that a 'failure complex' was a socio-psychological obstacle to the effectiveness of development policy and assistance.

Hirschman's ideas were dismissed, though, by the institutional prescriptions of the multilateral lenders and western development agencies, based on the argument that he ignored the difficulties on the ground. So it is striking that, to a degree, the choices of the Chinese intermediaries conform to Hirschman's ideas. When the focus is on quick infrastructure building, organisational design escapes from the straightjacket of preconditions for receiving western assistance ${ }^{46}$. Instead, organisations are encouraged to take risks and be pragmatic, and organisational choices rely on the participants' capacity for improvisation, ingenuity, creativity and flexibility to solve problems. In alignment with Hirschman's prescriptions, these interorganisational contexts evolve by trial and error, and rely on learning-by-doing to eliminate bottlenecks to their evolution and growth.

\footnotetext{
${ }^{45}$ Hirschman 1967,1975

${ }^{46}$ Hirschman 1971
} 
Our collection of studies reveals mixed results about interorganisational contexts wholly focused on infrastructure building. While the surrounding institutions may be weak and underdeveloped, these interorganisational contexts rarely operate in a vacuum. And when creativity, improvisation and flexibility fail to eliminate emerging bottlenecks, these contexts unravel and fail. Still, faced with the certainty that a focus on building institutions cannot offer quick solutions to urgent problems, many African states are happy to take the bargain offered by Chinese actors. This suggests a duality in that the two objectives are desirable. The challenge remains that organising for one pole of the duality is incompatible with organising for the other. However, there is equi-finality in that the system-level goal unifying the participants in both forms of organising is the same - socio-economic development. And neither approach is superior to the other. The traditional approach struggles to tackle basic infrastructure gaps; as for the emergent approach, it is too soon to know how its outcomes will play out in the long term. But the evidence assembled here is suggestive of mixed results.

More certain seems the fact that this duality is here to stay, as China emerges as the world's biggest economy, and its more transactional-based, mercantilist order gains traction. Amplifying this duality are the fiscal pressures on advanced economies, and the doubts about their own models of democracy, individual freedom, rules-based order and market economies to successfully manage their own affairs in the aftermath of the financial crisis and the rise of populism. ${ }^{47}$ For certain, this new global order takes us beyond traditional boundary conditions in organisational studies. It also suggests a trove of new research questions to further our understanding of designing organisations for development and to navigate institutional voids more generally. These might include:

- When does stakeholder engagement cause more harm than good?

${ }^{47}$ We leave it to historians to strike potential parallels with the way in which the rise of Japan also challenged the global uniformities in the state, political ideologies and economic life imposed on the world by the western domination centuries before; Bayly 2004 
- Can too much transparency and accountability become hindrances to performance?

- Is orderly and transparent growth worth the added transaction costs and delays?

- Is fast-tracking and opaque growth worth the risk of disarray and value destruction?

- Can ambidextrous systems be designed to address both poles of the duality?

- Can informal activities be leveraged to compensate for the less desirable effects of formal activities?

- How does the quality of the institutions in the environment influence the choice to focus on one pole of the duality to the detriment of the other?

- Are there merits in the co-existence of the two forms of organizing?

It is not the purpose of this book to provide the answers to these, and other, emerging complex questions. But, by illuminating this design duality, we hope more research will ensue on designing organisations to tackle grand challenges in institutionally undeveloped settings.

\section{Final Considerations}

Our focus on how intermediaries directly influence choice in organisational design should not be interpreted to mean that we feel this is the crux of tackling grand societal challenges in institutionally underdeveloped environments. Choices in organisational design are not only determined by institutions, and these institutions are not the single cause that determines how actors behave ${ }^{48}$. For example, some studies here make clear that modular technologies that require less interorganisational cooperation and coordination, eg off-grid solar power, change the structure of the focal problem. And though we do not have a case on telecom infrastructure development, the rapid expansion of mobile phone use in Africa can be attributed in part to its more decomposable architecture. Modular technologies may thus hold the key for effective alternative organisational solutions. Nonetheless, institutions are an

\footnotetext{
${ }^{48}$ Ostrom 2005
} 
element that directly affects organisational design, and we still know little on designing organisations to overcome institutional shortcomings.

Our choice to focus on logic linking intermediation and organisation design choices also reflects our sense that, with China's economic rise and the advanced economies hobbled by populism and fiscal pressures, a new global order is settling in. And this raises new questions that require major attention. The Chinese involvement in Africa is historically unprecedented and likely to remain opaque — as the China Eximbank president said, 'If the water is too clear, you don't catch any fish' ${ }^{49}$ This sentiment could not contrast more with the western approach, which is also unlikely to change if we go by the words of the World Bank’s 2017 World Development Report - 'Development assistance can be more effective when donor engagement supports the emergence of more accountable and equitable governing arrangements that become embedded in the domestic context'. By foregrounding this duality, we are not suggesting the abandonment of principles entwined within the traditional approach. But neither does it mean we do not see value in the emergent approach. It may well be the case that superior solutions lie in organisational designs that combine the two approaches. It may also be the case that different approaches are better suited for differing infrastructure developments, according to the attributes of the focal problem. We can also expect the quality of the institutions to determine whether organisational designers have agency at all. To sum up, we leave this book with a new set of research questions for which we do not yet have answers. But we do claim there is a fundamental duality in designing organisations to navigate institutional voids, which presents new opportunities to reset the debate. A new dawn awaits; it is up to us to find the ways to make the best of it, and put it to good use today.

\footnotetext{
${ }^{49}$ Brautigam 2009: 296
} 


\section{References}

African Development Bank (2018). African Economic Outlook. African Development Bank

Bayly, C. 2004. The Birth of the Modern World 1780-1914. Global Connections and Comparisons. Blackwell. Oxford

Birkinshaw, J., Gibson C. 2004. Building ambidexterity into an organisation.MIT Sloan Management Rev. 45(4) 47-55

Bräutigam, D. 2009. The dragon's gift: The real story of China in Africa. Oxford University Press

Bräutigam, D. 2011. Aid 'with Chinese characteristics': Chinese foreign aid and development finance meet the OECD-DAC aid regime. J. of International Development 23, 752-64

Brewer, N. 2008. The New Great Walls. A Guide to China's Overseas Dam Industry. Berkeley, CA: International Rivers

Burnside, C., Dollar, D. 2000. Aid, Policies, and Growth. American Economic Review 90 (4) 847-68

Chabal, P., Daloz, J-P. 1999. Africa Works. Disorder as Political Instrument. Oxford: James Currey; Bloomington and Indianapolis, IN: Indiana University Press, in association with the International Institute

Chandler, AD. Jr. 1977. The Visible Hand: The Managerial Revolution in American Business. The Belknap Press of Harvard University Press

Chen, S., Ravallion, M. 2008. The developing world is poorer than thought but no less successful in the fight against poverty. Policy research working paper 4703. Washington, DC: World Bank

Collier P. 2009. The political economy of state failure. Oxford Review of Economic Policy 25(2): 219-240

Colquitt, J.A., George, G. 2011. Publishing in AMJ: Topic choice. Academy of Management Journal, 54: 432-435

Doh, J., Rodrigues, S., Saka-Helhout, A., Makhija, M. 2017. International business responses to institutional voids. J. International Business Studies 48, 293-307

Dutt, N., Hawn, O., Vidal, E., Chatterji, A., McGahan, A., Mitchell, W.2016. How Open System Intermediaries Address Institutional Failures: The Case of Business Incubators in Emerging-Market Countries ACAD MANAGE J June 59:818-840

Eisenhardt, KM., Graebner, ME., Sonenshein, S. 2016. Grand Challenges and Inductive Methods: Rigor without Rigor Mortis ACAD MANAGE J August 2016 59:1103-112

Erdmann, G., Engel U. 2006. Neo-patrimonialism Revisited: Beyond a Catch-All Concept'. GIGA Research Paper No. 16. Hamburg: German Institute of Global and Area Studies

Esfahani, H., Ramirez M. 2003. Institutions, infrastructure and economic growth. Journal of Development Economics, 70,443-477

Eom, J., Hwang, J., Atkins, L., Chen Y., and Zhou, S. 2017. China Africa Research Initiative. School of Advanced International Studies Policy Brief No. 18 John Hopkins University

Evans, P., Doz., Y. 1989. The dualistic organisation. A. Laurent, ed. Human Resource Management in International Firms. Macmillan, Basingstoke, UK

Ferraro F., Etzion D., Gehman J. 2015. Tackling grand challenges pragmatically: Robust action revisited. Organisation Studies, 36: 363-390

Fjeldstad, ØD., Snow, CC., Miles, RE., Lettl, C. 2012. The architecture of collaboration. Strategic Management Journal, 33, 734-750 
Flyvbjerg, B., Bruzelius, N., Rothengatter, W. 2003. Megaprojects and Risk: An anatomy of Ambition. Cambridge University Press

Frischman, BM. 2012. Infrastructure: The Social Value of Shared Resources. Oxford University Press

George, G., Corbishley, C., Khayesi, JNO., Haas, MR., Laszlo Tihanyi, L. 2016. Bringing Africa In: Promising Directions for Management Research Academy of Management Journal, 59:377-393

Gil, N. 2007. On the Value of Project Safeguards: Embedding Real Options in Complex Product and Systems. Research Policy, 36 (7) 980-99

Gil, N. 2009. Project Safeguards: Operationalizing Option-Like Strategic Thinking in Infrastructure Development IEEE Transactions on Engineering Management, 56 (2) May

Gil, N., Pinto. J. 2018. Polycentric Organising and Performance. A Contingency Model and Evidence from Megaproject Planning in the UK. Research Policy, 47, 717-34

Gil, N., Pinto, J. 2018. Avoid or Exploit Institutional Voids? Organisational Duality in the Design of Capital-intensive Project Organisations in Sub-Saharan Africa

Gulati, R., Puranam, P., Tushman, M. 2012. Meta-organisation design: Rethinking design in interorganisational and community contexts. Strat. Mgmt. J. 33: 571-586

Gulati, R., Puranam, P. 2009. Renewal through Reorganisation. Organisation Science 20 (2) $422-40$

Gumbo, T., Musonda, I., Bwanyire, B., Musakwa, W., Okoro, C. 2018. No one-size-fitsall solution: Learning form rapid rail development in Ethiopia and South Africa

Hamukoma, N., Levy, B. 2018. When the quest for electricity reform and the need for investment collide: South Africa, 1998-2004

Henderson, J. 2008. 'China and Global Development: Towards a Global-Asian Era?' Contemporary Politics 14(4): 375-92

Henderson, J., Appelbaum, RP., Ho, SY. 2013. Globalization with Chinese Characteristics: Externalization, Dynamics and Transformations. Development and Change, 44: 1221-53

Henisz, WJ., Dorobantu, S., Nartey, LJ. 2014. Spinning gold: The financial returns to stakeholder engagement. Strategic Management Journal, 35(12), 1727-1748

Hellowell, M. 2018. Delivering healthcare infrastructure and services through public private partnerships - the Lesotho case

Hernandez D. 2017. Are 'New' Donors Challenging World Bank Conditionality? World Development 96, August, 529-549

Hermes, N., Lensink, R. 2001. Changing the Conditions for Development Aid. A New Paradigm Ed. by N. Hermes and R. Lensink. London, Frank Cass.

Hirschman, AO. 1967. Development projects observed. Washington, DC Brookings Institution

Hirschman, AO. 1971. Introduction: Political Economics and Possibilism, in A.O. Hirschman A Bias for Hope: Essays on Development and Latin America, 1-37. New Haven, CT: Yale University Press

Hirschman, AO. 1975. Policymaking and Policy Analysis in Latin America: A Return Journey, Policy Sciences6: 385-402

Hoorweg, D., Pope, K. 2017. Population predictions for the world's largest cities in the 21st century. Environment and Urbanization 29 (1) 195-216

IEA 2016. World Energy Outlook 2016. International Energy Agency, Paris

IRENA 2014. REmap 2030. A Renewable Energy Roadmap. International Renewable Energy Agency, June, Abu Dhabi

Ismail, Metcalfe and McPherson. 2018. Centralized vs. Decentralized Generation in Zambia: Meeting Electricity Demand in the Context of Climate Change 
Karplus VJ., Lessard, DR., Rajpurkar, N., Singh A. 2018. Institutional enablers of energy system transition: Lessons from solar PV in eight African countries

Khanna, T., Palepu, KG. 1997. Why focused strategies maybe wrong for emerging markets. Harvard Business Review, 75, 41-51

Khanna, T., Rivkin, J. 2001. Estimating the performance effects of business groups in emerging markets. Strategic Management Journal, 22(1), 45-74

Khanna, T., Palepu, KG. 2010. Winning in emerging markets: A road map for strategy and execution. Boston: Harvard Business Press

Klingebiel, R., Stadler, C. 2015. Opportunities and challenges for empirical strategy research in Africa, Africa Journal of Management, 1:2, 194-200

Knudsen T., Srikanth K. 2014. Coordinated exploration: Organising joint search by multiple specialists to overcome mutual confusion and joint myopia. Administrative Science Quarterly, 59: 409-441

Lavagnon, AI. 2018. Beneficial or Detrimental Ignorance: The Straw Man Fallacy of Flyvbjerg's Test of Hirschman's Hiding Hand. World Development, 103, 369-382

Lawrence, PR., Lorsch, JW. 1967. Differentiation and integration in complex organisations. Administrative Science Quarterly, 12: 1-47

Lenfle, S. and Loch, C. 2010. Lost Roots: How Project Management Came to Emphasize Control over Flexibility and Novelty 'California Management Review, 53(1) 32-55

Levy, B. 2014. Working with the grain: Integrating governance and growth in development strategies. New York, NY: Oxford University Press

Libecap, GD. 1989. Contracting for Property Rights. Political Economy of Institutions and Decisions. Cambridge University Press

Love, PED., Ahiaga-Dagbui, DD. 2018. Debunking fake news in a post-truth era: The plausible untruths of cost underestimation in transport infrastructure projects, Transportation Research Part A, 113, 357-368

Luo X., Chung C. 2013. Filling or abusing the institutional void? Organisation Science, 24: 591-613

Mair J., Marti, I. 2009. Entrepreneurship in and around institutional voids: A case study from Bangladesh. Journal of Business Venturing, 24: 419-435

Mair, J., Marti, I., Ventresca, M. 2012. Building inclusive markets in rural Bangladesh: How intermediaries work institutional voids. Academy of Management Journal, 55: 819-850

Marshall, MG., Cole, BR. 2008. Global report on conflict, governance, and state fragility 2008. Foreign Policy Bulletin 18(1): 3-21

Martens, B. 2005. Why do Agencies Exist? Development Policy Review, 23 (6) 643-63

McDermott G., Corredoira R., Kruse G. 2009. Public-private institutions as catalysts of upgrading in emerging market societies. Academy of Management Journal, 52: 1270-96

Mohan, G., Lampert, B. 2013. Negotiating China: Reinserting African agency into ChinaAfrica relations, African Affairs, 112 (446) 92-1

McLean, EV., Schneider, CJ. 2014. Limits of informal governance? The scope of conditionality in the World Bank. Annual Meeting on the Political Economy of International Organisations, Princeton

Miller, R., Lessard, D. 2000. Public Goods and Private Strategies: Making Sense of Project Performance. In The Strategic Management of Large Engineering Projects. Roger Miller and Donald Lessard (eds). Cambridge, MA, MIT Press

Morris, PW. 1994. The management of projects. Thomas Telford

Naim, M. 2007. 'Rogue Aid', Foreign Policy 159: 95-96

Nadim, WH. 2018. A proactive social infrastructure model for future mixed-use housing in Egypt: A case study in Greater Cairo 
North, D. 1990. Institutions, Institutional Change, and Economic Performance Cambridge, England, Cambridge University Press

North, DC., Wallis, J., Weingast, B. 2009. Violence and Social Order: A Conceptual Framework for Interpreting Recorded Human History. Cambridge University Press

North, DC., Weingast, BR. 1989. Constitutions and Commitment: The Evolution of Institutions Governing Public Choice in Seventeenth Century England. The Journal of Economic History, 49 (4) 803-832

OECD. 2007. Infrastructure to 2030 (Volume 2): Mapping Policy for Electricity, Water and Transport. Paris: OECD Publishing

Ostrom, E. 1990. Governing the commons: The evolution of institutions of collective action. New York, NY: Cambridge University Press

Pinkham, BC., Peng, MW. 2016. Overcoming institutional voids via arbitration. Journal of International Business Studies

Rodrick, D. 2006. Goodbye Washington Consensus, Hello Washington Confusion, J. of Economic Literature, 44 (4) 973-87

Rose, A., Pérez-Arriaga, I., Stoner, R., de Neufville, R. 2018. Harnessing Africa’s Energy Resources Through Regional Infrastructure Projects

Scott, WR. 1981. Organisations: Rational, Natural, and Open Systems. Englewood Cliffs NJ: Prentice Hall Inc

Simon, HA. 1981. The Sciences of the Artificial, 2nd Ed. Cambridge, MA: MIT Press

Smith, WK., Tushman, ML. 2005. Managing strategic contradictions: A top management model for managing innovation streams. Organisation Science 16(5) 522-536

Stafford, A., Stapleton, P., Boateng, A. 2018. Achieving long-term financial sustainability in African infrastructure projects

Tan-Mullins, M., Mohan, G. and Power, M. 2010. Redefining 'Aid' in the China-Africa Context. Development and Change, 41: 857-881

Thompson, JD. 1967. Organisations in Action. New York: McGraw-Hill Managing Differentiation and Integration. Boston, Massachusetts: Harvard University

Trigeorgis, L. 1996. Real Options: Managerial Flexibility and Strategy in Resource Allocation. MIT Press, Cambridge

Tull, D. 2006. China's Engagement in Africa: Scope, Significance and Consequences, Journal of Modern African Studies 44(3): 459-79

UN-Habitat. 2016. World Cities Report 2016. Urbanization and Development: Emerging

Futures. Key Findings and Messages. UN Habitat, Nairobi, Kenya

UN-Habitat. 2011. Infrastructure for Economic Development and Poverty Reduction in Africa. Nairobi: UN-Habitat

UN. 1995. Public Sector Management, Governance, and Sustainable Human Development: UN Development Programme New York

UN. 2011. The Millennium Development Goals Report 2011. New York: United Nations

UN. 2013. Financing for Sustainable Development. UN task team on the post-2015 UN

Development Agenda, Executive summary. United Nations

UN. 2017. World Population Prospects: The 2017 Revision, Department of Economic and Social Affairs, Population Division, New York, United Nations

UN. 2018. The United Nations World Water Development Report. UN water

van Dijk, MP. 2009. The new presence of China in Africa. Amsterdam: Amsterdam University Press

Williamson, OE. 1985. The economic institutions of capitalism. Free Press: New York

Wily, LA. 2011. 'The Law is to Blame': The Vulnerable Status of Common Property Rights in Sub-Saharan Africa. Development and Change, 42: 733-757 
Wissenbach, U. 2018. Kenya's Madaraka Express - an example of the decisive Chinese impulse for African Mega Infrastructure projects

World Economic Forum. 2017. The Global Competitiveness Report 2018-2018. Editor Klaus Schwab. World Economic Forum, Geneva

Woods, N. 2008. 'Who's Aid? Who's Influence? China, Emerging Donors and the Silent Revolution in Development Assistance', International Affairs 84 (6): 1205-21

Worch, H., Kabinga, M., Eberhard, A., Markard, J., Truffer, B. 2018. Why the Lights Went Out: A Capability Perspective on the Unintended Consequences of Sector Reform Processes

World Bank 1994. World development report: Infrastructure for development. New York: Oxford University Press

Chapters 2- 13

\section{Afterword}

\section{Nuno Gil, Alliance Manchester Business School}

As we prepared to wrap up this book and send all the chapters to our publisher, I had the chance to travel to Africa to test, with a group of local scholars and policy makers, the central argument: That underlying the diversity of observed interorganisational contexts set up to promote socioeconomic development by ways of tackling gaps in basic infrastructure lies a duality of building institutions and building infrastructure - two desirable objectives with underlying design attributes that make them organizationally incompatible. The setting was the city of Livingstone, a stone's throw from majestic Victoria Falls - two places charged with references to a bygone western colonial era which, for good and for ill, is part of Africa's history. But also an era from which there is little to learn in terms of designing interorganisational contexts to equip Africa with much-needed infrastructure to cope with the conflation of rapid population growth, increasing urban migration and climate change. It was heartening that our audience bought into our core idea and related to the dilemma that we believe faces organization designers. But pertinent questions were also raised as to where this 
'duality' leaves us, and if the focus on either pole of the duality exhausts the solution space of interorganisational contexts that can be designed in order to tackle grand challenges when there is a shortfall of institutions.

Working on this book as lead editor for two years gave me the opportunity to think hard and long about these questions. As the body of evidence accumulated, the difficulties on the ground in designing interorganisational contexts capable of reconciling the two objectives became very apparent. But we should not rush to accept that we are stuck between a highstakes gamble - choosing to focus on building basic infrastructure despite institutional shortcomings, which amplifies the risks of corruption, bribes, and organisational collapse and delaying infrastructure building until the institutions are first developed, which creates a real risk of not building the basic infrastructure due to difficulties in building first the institutions. Indeed, accepting that there are no other choices would be remiss, considering the fast pace of Africa's population growth - in the two years that it took to produce this book, Africa's population - of which sixty percent are aged only 24 years old or younger increased about 65 million people, which is about the size of the UK's population!

Instead, we propose that, yes, there is an organizational duality between building institutions and building infrastructure. But this idea enables us to lay down a new research agenda and formulate questions that were previously overlooked because they were obscured by the debate between superior versus inferior organizational designs. Specifically, we need to investigate new ways to define and measure the performance of the organisational designs that can be set up to build infrastructure in order to pursue development. This duality suggests that western criteria to evaluate performance and value creation of interorganisational contexts set up to tackle gaps in basic infrastructure - criteria rooted in 'good' governance ideals and the project's time-cost-scope golden triangle - are inadequate. These criteria rightly recognise the value of institutions building but wrongly ignore the elapsed time 
incurred to develop basic infrastructure. And compressing this time is a desirable objective, too. But if allowing for a degree of informal private gains, opacity and lack of accountability for public spending may be necessary evils to fast-track infrastructure building, where do we draw the line? How can we ensure that this will not end up simply allowing individual predators to appropriate common resources in order to serve the private interests of a restricted few? Furthermore, at what point in the evolution of the institutions in the context can we rule out the idea of exploiting institutional voids in the pursuit of socioeconomic development by means of building basic infrastructure? Or put differently, what contingencies in the environment determine when organizational designers should prioritise one pole of the duality over the other?

We should also not allow the idea of a design duality to force us into thinking that a search for forms of organizing that are more ambidextrous is the answer for socioeconomic development. 'Seeing' a duality is not the same as saying this duality exhausts the space of the organizational designs that are possible. And our evidence does suggest other viable organizational designs. The self-governance structure designed by the Cairenes to improve living and working conditions in the informal settlements is a case in point. And so is the public-private arrangement that enabled the development of South Africa's Gaultrain railway system without involving an intermediary - a testament to local success in building institutions.

Allow me to advance here an analogy with how African Bushmen see the survival of prey species for carnivores. Zebras, giraffes, impalas, gnus and other species graze in mixed herds. By sharing the abundant resources of the savannah, they all gain heightened awareness of potential predators. With their long necks, giraffes see predators at greater distances, zebras have superb hearing, and impalas and gnus bring large numbers to the group. In other words, each species brings with it a set of unique complementarities that altogether help to 
keep at bay the predators that are hidden in the bush. Of course, we all know that predators occasionally succeed. But the Bushmen believe that by grazing together and sharing the resources of the savannah, the multiple species are increasing their own individual chances of survival.

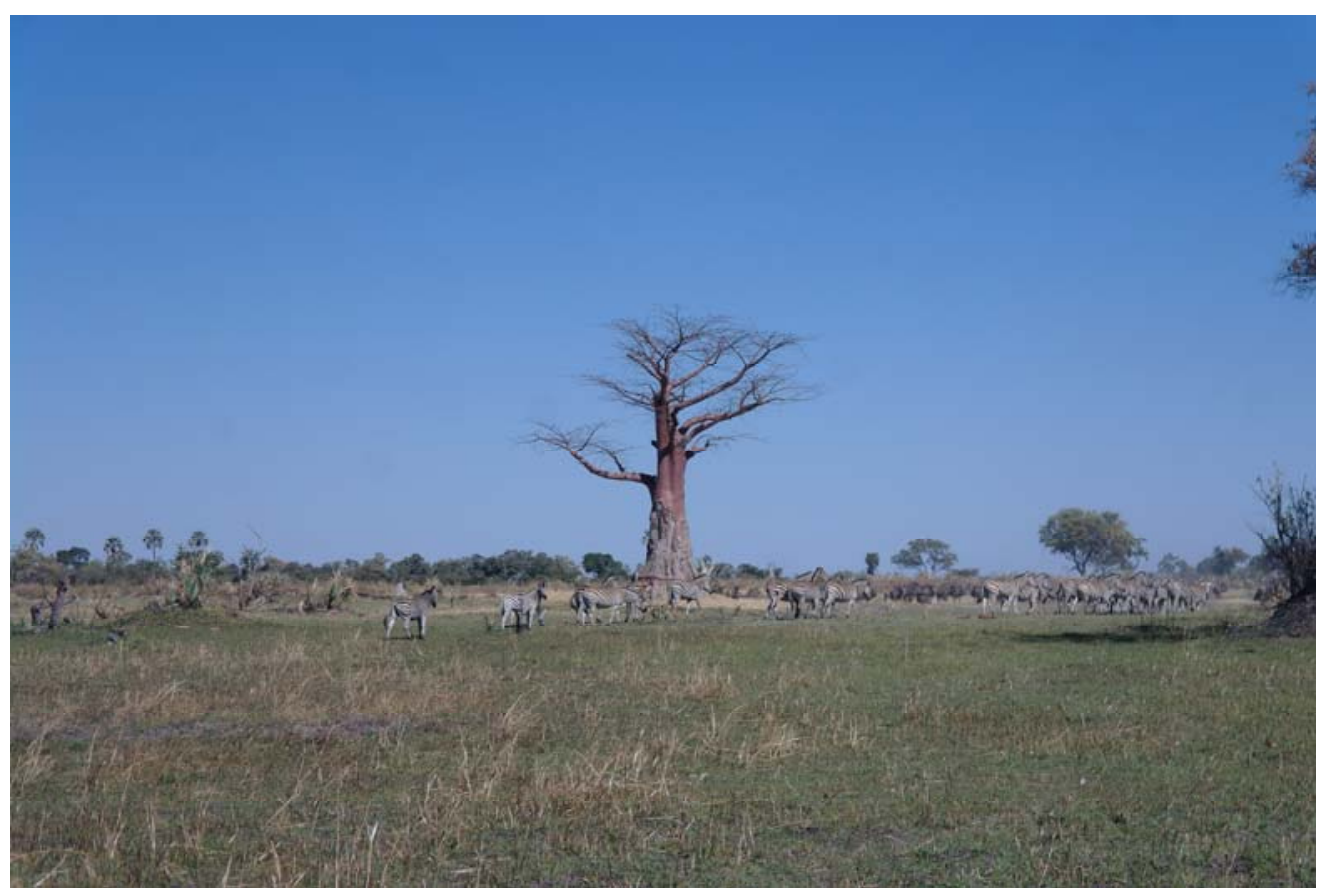

Figure 1 - A mixed herd sharing the natural resources of the savannah

The body of evidence assembled for this book does not suggest that one single group of intermediaries holds all the cards to help the African governments in their struggle to bridge gaps in basic infrastructure. On the contrary, the evidence suggests that the governments of emerging economies have agency to make choices between differing organisational designs. And crucially, the evidence also suggests that we should not be naïve. Lurking in any institutionally underdeveloped landscape are predators - interorganizational contexts designed with the sole purpose of appropriating public resources for maximizing private gains. But I conjecture that a diversified population of organizational designs better equips 
African countries to chase socioeconomic development, while fending off attacks from the predators that are keen to exploit the continent's abundant common resources. ${ }^{50}$

In sum, working on this book has opened my eyes to two different ways of seeing efforts by which intermediaries seek to help the governments of emerging economies to pursue socioeconomic development. This is not a story about searching for the superior form of organizing; it's a story about complementarity between forms of organising at the two poles of a duality. I am also not arguing that espousing informal private gains is a prerequisite for development. Or that there is, or there is not, moral equivalence at the two poles of the duality. But I am, nevertheless, convinced that we all gain more than we lose in 'seeing' this duality. This duality exists by design. This does not mean this way of looking out alone offers us solutions to equip Africa with much-needed basic infrastructure and institutions to cope with 4.5 billion people by 2100 . Or for accommodating the largest cities on earth, such as Lagos, Kinshasa, Dar es Salaam, Khartoum and Niamey, all projected to exceed 55 million people by 2100. But perhaps by framing the problem in this way, we will see new organisational designs and complementarities that can be mobilised to tackle this grand challenge of our time; solutions that, until now, were invisible to us.

One thing is clear: There is no time to waste. The evidence is in front of us for those who want to see it. As I set off to leave Africa, I left behind a long queue of trucks waiting to cross the river Zambezi at the border between Botswana and Zambia by pontoon ferry. Locals claim that the average waiting time for a truck to cross is around two weeks. A new bridge to open up trade and promote tourism is expected to open by 2019. But the stubborn fact that the nearest alternative is the Victoria Falls bridge, completed in 1905, is cause for thought.

${ }^{50}$ My children call it the 'Savannah theory'. We are no way near there, yet. But the thought was much appreciated. 
Equipping Africa with basic infrastructure as well as institutions is the fight of our lives.

It is a global race. But not a race where there are individual winners and losers. It is a race against time. If we succeed, we all win. But if we should fail, humanity loses.

\author{
Nuno Gil, Manchester 2018
}

\title{
PREVIEW OF ENDORSEMENTS
}

Africa's capacity for prosperity - which relies centrally on its infrastructure - is central to our way of life for a slate of reasons that are laid out in this terrific book. Gil explains what it will take to develop the infrastructure necessary to assure stability and security. This is essential reading for scholars interested in the construction of institutions, and for anyone interested in international political economy, Anita McGahan, Professor of Strategic Management and George E. Connell Chair in Organizations \& Society at Rotman

"With a wealth of empirical evidence, this book exposes a fundamental choice underlying infrastructure development in Africa and elsewhere. Western development agencies emphasize institution-building, good governance and transparency with the result that investment is slow. In contrast, Chinese agencies seek to "get it done" so that investment is quick, but possibly unsustainable. Foreshadows a new era of geopolitics on the African continent." - Carliss Y. Baldwin, Harvard Business School

\footnotetext{
This book presents a new, probing and insightful slant on the well-trodden discussion of the duality involved in promoting infrastructure development in emerging market countries with weak institutions: "Is it better to support painfully slow and steady enhancement of local institutions to create stronger and more transparent local capabilities for managing infrastructure service delivery in the public interest, or, is it better to enhance infrastructure services to citizens more rapidly by using external financing and expertise to develop projects rapidly, in spite of-or by exploiting-the extant weak institutions and yawning institutional gaps in these countries in the hope that the broad societal prosperity thus generated will ultimately lead to better governance?" Rather than treating this as a dilemma with dichotomous alternatives, each with its pros and cons, this book delivers hard-hitting arguments and multiple case studies to support the idea of looking for hybrid organizational solutions that can maximize the benefits and minimize the risks of both approaches. It poses questions that can help to launch a new set of research and experimentation in support of the aspirations and goals of both the local populations and the grantee countries and multilateral institutions that support infrastructure development. It is well worth a read!
}

Raymond E. Levitt, Kumagai Professor of Engineering Emeritus, and Director, The Global Projects Center, Stanford University.

Africa has a rapidly growing population, which is projected to reach $40 \%$ of the world's population by 2100 . This rapid growth in population highlights the challenges presented by an infrastructure which is already woefully inadequate.Drawing on an extensive body of research, this book focusses on the incompatibility between building institutions and capital investment, a fundamental question that will become ever more pressing as the growth in population demands better infrastructure to serve it. The Western approach of institutional building as a necessary precursor to investment contrasts sharply with the Chinese focus on speed of investment, a contrast which will become more sharply drawn and debated in the future. This book makes a valuable contribution to that debate and is essential reading for all those interested in the provision of 
infrastructure to meet the needs of the growing population of Africa.

Dr John Roberts CBE, FREng

Former CEO, United Utilities.” 